\title{
Dampak Kepemimpinan, Iklim Sekolah dan Motivasi Berprestasi Dalam Meningkatkan Komitmen Guru
}

\author{
Lukman Hakim*, Bukman Lian, Alhadi Yan Putra \\ Universitas PGRI Palembang, Indonesia \\ *lukmanhkm82@gmail.com
}

\begin{abstract}
The purpose of this study was to determine and analyze the effect of significantly leadership principal, school climate and commitment achievement motivation to teachers at SMK Sub Rayon 04 in Ogan Komering Ulu Timur regency of South Sumatra province either partially or simultaneously. This study was a quantitative descriptive research, the population in this study are all public school teachers in the SMK Sub Rayon 04 in Ogan Komering Ulu Timur regency of South Sumatra province 330 teacher, with a sample of 101 teachers. Data was collected by questionnaire. Analysis of data using path analysis (path analysis) and bypothesis testing. The results of this study indicated that Leadership Principal significantly influence teachers' commitment, school climate significant effect on teacher commitment, achievement motivation significant effect on the school climate of teachers. Leadership principal, school climate, achievement motivation jointly significant effect on commitment of teacher.
\end{abstract}

Keywords: motivation, commitment, leadership

\section{ABSTRAK}

Tujuan penelitian ini adalah untuk mengetahui dan menganalisis pengaruh signifikan kepemimpinan kepala sekolah, iklim sekolah dan motivasi berprestasi terhadap komitmen guru di SMK Sub Rayon 04 Kabupaten Ogan Komering Ulu Timur Provinsi Sumatera Selatan baik secara parsial maupun secara simultan. Penelitian ini termasuk dalam jenis penelitian deskriptif kuantitatif, populasi pada penelitian ini adalah seluruh guru SMK Sub Rayon 04 Kabupaten Ogan Komering Ulu Timur Provinsi Sumatera Selatan sebanyak 330 guru, dengan sampel 101 guru. Pengumpulan data dilakukan dengan kuisioner. Analisis data menggunakan analisis jalur (path analysis) dan pengujian hipotesis. Hasil penelitian ini menunjukkan bahwa kepemimpinan kepala sekolah berpengaruh signifikan terhadap komitmen guru, iklim sekolah berpengaruh signifikan terhadap komitmen guru, motivasi berprestasi berpengaruh signifikan terhadap komitmen guru. Kepemimpinan kepala sekolah, iklim sekolah, motivasi berprestasi secara bersama-sama berpengaruh signifikan terhadap komitmen guru.

Kata Kunci: kepemimpinan, komitmen, motivasi

Submitted: May 25, 2021 | Revised: Jun 16, 2021 | Accepted: Jun 21, 2021

\section{Pendahulua}

Pendidikan sering diartikan sebagai usaha manusia untuk membina kepribadian sesuai dengan nilai-nilai di masyarakat. Pendidikan merupakan sebagai pondasi dasar dari kemajuan suatu bangsa dengan menciptakan sumber daya manusia yang berkualitas. Untuk menghasilkan sumber daya yang berkualitas diperlukan juga seorang guru pendidik yang berkualitas juga. Untuk menghasilkan guru pendidik yang berkualitas dipengaruhi oleh berbagai faktor terutama kepemimpinan kepala sekolah. Kepala sekolah memegang peran yang sangat penting karena kepala sekolah bertanggung jawab penuh untuk mengelola dan memperdayakan guru-guru agar terus meningkatkan komitmen dalam bekerjanya.

Menurut Mastuhu (2003:109), mutu pendidikan menjadi hal penting dalam rangka meningkatkan persaingan global maka pengelolaan komponen pendidikan harus perlu mendapatkan perhatian yang serius. Manusia sebagai salah satu komponen instrumental input yang merupakan faktor penting sebagai penentu pencapaian suatu tujuan karena ketercapain tergantung pada the man behind the gun. Berhasil tidaknya penyelenggaraan pendidikan yang bermutu dipengaruhi oleh jumlah dan mutu para aktor yang melaksanakannya. 
Berkaitan dengan komponen sistem pendidikan dan menurut Kristiawan (2014) peran guru menjadi penentu keberhasilan misi pendidikan dan pembelajaran disekolah, guru bertanggung jawab mengatur, mengarahkan, dan menciptakan suasana kondusif yang mendorong siswa melaksanakan proses pembelajaran. Guru memiliki peran penting dalam pendidikan bahkan sumber daya pendidikan lain, dengan kata lain guru merupakan ujung tombak dalam upaya peningkatan kualitas layanan dan hasil pendidikan. Komitmen guru juga berpengaruh langsung terhadap kualitas pendidikan setiap peserta didik, semakin baik komitmen guru maka semakin berkualitas pendidikan yang dihasilkan, dengan kata lain apabila guru memiliki komitmen yang bagus maka hasil proses belajar mengajar juga akan bagus.

Kepemimpinan merupakan norma perilaku yang dipergunakan oleh seseorang untuk mempengaruhi orang lain, kepemimpinan banyak mempengaruhi keberhasilan dalam mempengaruhi bawahan iklim sekolah dan motivasi terhadap komitmen guru tidak lepas dari pengaruh kepemimpinan kepala sekolah, prioritas yang utama dilakukan oleh kepala sekolah yaitu memperbaiki ataupun meningkatkan mutu pendidikan, memegang peranan penting dalam pencapaian tujuan yang maksimal. Menurut Ahmad (2013) kepemimpinan adalah proses memengaruhi dan dipengaruhi antara yang memimpin dan dipimpin untuk mencapai suatu tujuan. Kepemimpinan adalah kemampuan untuk membangkitkan semangat orang lain agar bersedia dan memiliki tanggung jawab total terhadap usaha mencapai atau tujuan organisasi, seorang pemimpin yang baik harus memiliki beberapa karakteristik yaitu tanggung jawab seimbang, model peranan yang positif, memiliki keterampilan komunikasi, memiliki pengaruh positif dan memiliki kemampuan meyakinkan orang lain (Nasution, 2010).

Menurut Depdiknas (2006), kepala sekolah selaku pimpinan tertinggi di sekolah dianggap berhasil jika dapat meningkatkan komitmen guru melalui berbagai macam bentuk kegiatan pembinaan terhadap kemampuan guru dalam melaksanakan pembelajaran di sekolah. Oleh sebab itu, kepala sekolah harus mampu menjalankan peran dan tanggung jawabnya sebagai seorang educator, manager, administrator, supervisor, leader, inovator, dan motivator.

Usaha kepala sekolah dalam meningkatkan komitmen guru harus dilakukan dengan cara memilih iklim sekolah dan motivasi berprestasi apa yang harus dilakukan, adapun bentuk iklim sekolah berupa penilaian terhadap bawahan dan memperhatikan sarana dan prasarana sekolah, sedangkan motivasi berprestasi pada umumnya berupa uang dan barang juga non materi berupa pujian, sanjungan dan penghargaan. Mengingat sebuah iklim sekolah dan motivasi berprestasi merupakan faktor penggerak yang sangat mempengaruhi tingkah laku manusia, seorang guru yang memiliki iklim sekolah dan motivasi berprestasi tinggi dalam pekerjaannya tentu akan terdorong untuk melakukan pekerjaan secara efektif dan efisien sehingga tujuan yang sudah direncanakan dapat tercapai dengan baik. Iklim sekolah dan motivasi berprestasi yang dimiliki oleh setiap individu berbeda-beda, ada yang memiliki tinggi, rendah dan sedang semuanya akan berpengaruh terhadap komitmen yang dihasilkan. Menurut teori Atkinson bahwa kecendrungan sukses ditentukan oleh motivasi, peluang serta insentif, begitu juga sebaliknya dengan kecendrungan untuk gagal (Uno, 2007). Dari pandangan tersebut maka iklim sekolah motivasi berprestasi memiliki peran yang sangat penting dalam melaksanakan berbagai pekerjaan yang diemban oleh guru agar dapat mencapai tutujuan yang telah ditetapkan.

Iklim organisasi sekolah ditentukan oleh lingkungan internal dan lingkungan eksternal. Iklim sekolah merupakan presepsi guru terhadap situasi dan kondisi lingkungan sekolah baik fisik maupun non fisik. Perasaan tersebut berkaitan dengan lingkungan yang nyaman dan mendukung untuk kegiatan pembelajaran, bimbingan, keteraturan, dan keamanan yang dirasakan oleh personil sekolah. Iklim organisasi sekolah akan lebih terlihat pada prilaku staff, guru, kepala sekolah, siswa, dan personil sekolah lainnya. Iklim sekolah terlihat masih kurang kondusif dalam meningkatkan komitmen guru. Hal ini sangat terlihat dari sarana dan prasarana sekolah yang kurang memadai dan lingkungan fisik sekolah yang belum ditata dengan teratur. Secara umum tingkat kebersihan sekolah, seperti kelas, halaman, WC, dan kamar mandi masih cukup memprihatinkan, banyak siswa di sekolah yang tidak peduli dengan 
teman sebayanya, guru yang kurang perhatian terhadap kesulitan belajar siswa di sekolah, dan kepala sekolah tidak objektif dalam memberikan penilaian terhadap bawahannya.

Penulis menyimpulkan bahwa fungsi kepemimpinan kepala sekolah masih kurang. Sebagian kepala sekolah hanya menangani masalah administratif, memonitor kehadiran guru, atau membuat laporan kepada pengawas. Pemimpin kepala sekolah tidak memperhatikan karateristik para guru. Hal ini disebabkan karena keterbatasan waktu kepala sekolah yang bekerja sendiri tanpa dibantu oleh wakil atau staff sehingga waktu untuk memahami karateristik bawahan menjadi kurang. Kepemimpinan kepala sekolah dalam memimpin harus ditingkatkan lagi. Rendahnya tanggung jawab, terbatasnya wawasan kepala sekolah, pengangkatan kepala sekolah yang belum transparan, kurangnya sarana dan prasarana, lulusan yang kurang mampu berkompetisi, rendahnya kepercayaan masyarakat, birokrasi serta rendahnya produktivitas kerja (Mansur. 2018).

Pendidikan di sekolah bukan hanya tanggung jawab pemerintah dan warga sekolah saja melainkan juga tanggung jawab seluruh lapisan masyarakat. Hal ini sesuai dengan prinsip penyelenggaraan pendidikan sebagaimana diamanatkan oleh Undang-Undang Sistem Pendidikan Nasional, yaitu pendidikan diselenggarakan dengan memperdayakan semua kompeten masyarakat melalui peran serta dalam penyelenggaraan dan pengendalian mutu layanan pendidikan. Di samping itu, juga terdapat kewajiban masyarakat untuk memberikan dukungan sumber daya dalam penyelenggaraan pendidikan.

Motivasi berprestasi merupakan dorongan dalam diri orang-orang untuk mengatasi segala tantangan dan hambatan dalam upaya mencapai tujuan yang ingin berkembang dan tumbuh serta ingin maju menelusuri tangga keberhasilan (Tampubolon, 2016). Motivasi berprestasi merupakan tidak adanya kemauan untuk meningkatkan kemampuan dirinya sendiri dengan melanjutkan pendidikannya atau menambah ilmu pengetahuan yang dimilikinya dengan belajar secara pribadi, seperti membaca dan belajar teknologi, seperti internet untuk memberikan pengetahuan yang kian hari kian berkembang (Novitasari, et al, 2017; Cahyani, et al, 2020). Ketidak percayaan diri yang selalu meliputi dirinya karena minimnya ilmu pengetahuan yang dimiliki.

Penalaran ilmu kepada peserta didik hanya mengandalkan ilmu yang dimiliki tidak dapat mengembangkannya peserta didik sehingga mendapatkan pengetahuan yang kurang maksimal. Begitu juga dengan prestasi yang diperoleh banyak guru yang enggan mengikuti kegiatan-kegiatan yang dilaksanakan pemerintah, seperti workshop, pelatihan-pelatiahan keahlian, pengembangan kurikulum, dan kegiatan yang bersifat pengembangan diri.

Kenyataannya yang ada terdapat beberapa gejala-gejala yang menunjukkan rendahnya komitmen yang dimiliki oleh guru, yakni tingkat masuk dan keluarnya guru yang sangat memprihatinkan, keinginan untuk terus bersama organisasi kurang, dan tingkat kehadiran guru di sekolah yang masih rendah. Rendahnya komitmen guru juga disebabkan oleh berbagai alasan, yakni sarana-prasarana yang kurang memadai, motivasi berprestasi guru yang rendah, kepemimpinan kepala sekolah yang kurang baik terhadap guru, iklim sekolah yang kurang kondusif, penggajian guru yang tidak sesuai dengan beban kerja serta tingkat pendidikan, dan kualifikasi pendidikan yang tidak sesuai dengan bidang pekerjaan guru.

Hasil-hasil penelitian yang telah dilakukan pada penelitian Carson (2007), Morrison (2010), Fernandez, et al (2010), Organ (2007), Puffer (2002), O'Reilly dan Chatman (2001), Organ (2006), secara empiris mendukung adanya hubungan antara komitmen organisasi dan kepemimpinan kepala sekolah. Demikian halnya dengan penelitian Wahid (2011), menyatakan bahwa hasil penelitian mengindikasikan bahwa komitmen organisasi secara keseluruhan memiliki hubungan dengan perilaku kepala sekolah. Menurut Astina (2016), komitmen guru dan kepemimpinan kepala sekolah seringkali dipertimbangkan sebagai antasenden dalam penelitian. Perbedaan penelitian yang dilakukan terdahulu dengan yang peneliti lakukan adalah tempat penelitian, populasi, sampel, dan teori yang digunakan antara peneliti terdahulu dengan peneliti sekarang. Septiana melakukan penelitian di SMP Negeri Wonosari, Baihaqi di MA Ma’arif Selorejo Blitar dan Fauzi di SMP Negeri 3 Pabelan Kab. Semarang. 
Sedangkan yang akan dilakukan oleh peneliti yaitu pada guru yang ada pada suatu organisasi yang ada di Kabupaten Oku Timur Propinsi Sumatera Selatan, yaitu guru SMK se Sub Rayon 04 Kbupaten OKU Timur Propinsi Sumatera Selatan.

Tujuan dari penelitian ini adalah untuk menganalisis dan mendeskripsikan pengaruh kepemimpinan kepala sekolah, iklin sekolah dan motivasi beprestasi terhadap komitmen guru. Adapun manfaat dalam penelitian ini agar bisa digunakan oleh penelti selanjutnya sebagai bahan referensi yang berhubungan dengan kepimpinan, iklim sekolah, motivasi berprestasi dan komitmen.

\section{Metode Penelitian}

Metode yang digunakan dalam penelitian ini adalah metode deskriptif kuantitatif untuk melihat pengaruh secara parsial antara variabel-variabel yang ada. Penelitian ini dilaksanakan di SMK Sub Rayon 04 Kabupeten OKU Timur. Penelitian ini berlangsung dalam kurun waktu lebih kurang 2 bulan dimulai dari bulan Agustus sampai dengan September 2020.

Populasi dalam penelitian ini adalah seluruh guru yang mengajar di SMK Sub Rayon 04 di Kabupaten OKU timur tahun 2020 dimana terdapat 7 Sekolah dengan total 330 Guru. Selanjutnya Sampel adalah bagian dari jumlah dan karakteristik yang dimiliki oleh populasi tersebut (Sugiyono, 2012). Oleh karena itu sampel merupakan sebagian dari populasi yang hendak diteliti, dan mewakili dari keseluruhan populasi. Teknik pengambilan sampel dalam penelitian ini menggunakan simple random sampling yaitu cara pengambilan sample dari anggota populasi. Random sampling adalah pengambilan sampel secara acak dan sederhana. Sebuah sampel yang diambil sedemikian rupa sehingga setiap unit penelitian atau satuan elemen dari populasi mempunyai kesempatan yang sama untuk dipilih menjadi sampel (Kesumawati, 2017). Adapun dalam penelitian ini peneliti mempersempit populasi yaitu seluruh guru yang berjumlah 330 orang dengan menggunakan perhitungan rumus Slovin (Riduwan, 2010). Populasi dalam penelitian ini berjumlah 330 orang, sehingga kelonggaran dari presentasi yang digunakan adalah 10\% dan hasil dari perhitungan didapat 101 Guru.

Teknik pengumpulan data yang digunakan dalam penelitian ini menggunakan kuesioner. Adapun kuesioner yang akan digunakan untuk mengumpulkan data mengenai kepemimpinan kepala sekolah, iklim sekolah, motivasi berprestasi dan komitmen guru akan mengacu kepada skala likert.

\section{Hasil dan Pembahasan}

Pengujian hipotesis dilakukan untuk mengetahui apakah variabel-variabel Kepemimpinan, Iklim Sekolah dan Motivasi Berprestasi bepengaruh atau tidak terhadap Komitmen Guru. Untuk mengetahui hal tersebut, dilakukan beberapa perhitungan statistik diantaranya uji-t dan uji F.

1. Uji-t

Uji-t bertujuan untuk menguji koefisien regresi secara parsial guna mengetahui apakah variabel bebas secara individu berpengaruh terhadap variabel terikat seperti ditunjukkan pada tabel 1 .

\begin{tabular}{|c|c|c|c|c|c|}
\hline \multirow[b]{2}{*}{ Model } & \multicolumn{2}{|c|}{$\begin{array}{l}\text { Unstandardized } \\
\text { Coeficients }\end{array}$} & \multirow{2}{*}{$\begin{array}{c}\text { Standardized } \\
\text { Coefficients } \\
\text { Beta } \\
\end{array}$} & \multirow[t]{2}{*}{$\mathrm{t}$} & \multirow[t]{2}{*}{ Sig } \\
\hline & $\mathrm{B}$ & Std.Error & & & \\
\hline 1 (Constan) & -4.280 & 3.794 & & -1.128 & .262 \\
\hline Kepemimpinan Kepala Sekolah & .328 & .122 & .278 & 2.685 & .009 \\
\hline Iklim Sekolah & .282 & .135 & .259 & 2.083 & .040 \\
\hline Motivasi Berprestasi & .428 & .144 & .3 .92 & 2.975 & .004 \\
\hline
\end{tabular}

a.Dependent Variable : Komitmen Guru

Hasil perhitungan tersebut di atas diperoleh bahwa thitung untuk variabel kepemimpinan kepala sekolah sebesar 2.685, sedangkan $\mathrm{t}$ tabel dengan $\mathrm{dk}=101-3=98$ dan $=0,05$ diperoleh 1,984. Dengan demikian, $\mathrm{t}$ hitung $>\mathrm{t}$ tabel atau 2,685 $>1,984$ maka H0 ditolak dan H1 diterima berarti 
"Terdapat pengaruh yang signifikan kepemimpinan kepala sekolah secara langsung terhadap komitmen guru di SMK Sub Rayon 04 Kabupeten Ogan Komering Ulu Timur Provinsi Sumatera Selatan".

Selanjutnya, hasil perhitungan diatas diperoleh bahwa t hitung untuk variabel iklim sekolah sebesar 2,083, sedangkan t tabel dengan $\mathrm{dk}=101-3=98$ dan $=0,05$ diperoleh 1,984. Dengan demikian, $\mathrm{t}$ hitung $>\mathrm{t}$ tabel atau 17,935 >1,984, maka H0 ditolak dan H1 diterima berarti "Terdapat pengaruh yang signifikan iklim sekolah secara langsung terhadap komitmen guru di SMK Sub Rayon 04 Kabupeten Ogan Komering Ulu Timur Provinsi Sumatera Selatan".

Kemudian, hasil perhitungan di atas diperoleh bahwa t hitung untuk variabel motivasi berprestasi sebesar 2,978 t tabel dengan $\mathrm{dk}=101-3=98 \mathrm{dan}=0,05$ diperoleh 1,984. Dengan demikian, $\mathrm{t}$ hitung $>\mathrm{t}$ tabel atau 2,975 < 1,984 maka H1 diterima dan H0 ditolak berarti "Terdapat pengaruh yang signifikan motivasi berprestasi secara langsung terhadap komitmen guru di SMK Sub Rayon 04 Kabupeten Ogan Komering Ulu Timur Provinsi Sumatera Selatan".

2. $\mathrm{Uji} F$

Uji f bertujuan untuk melihat peran variabel bebas secara simultan terhadap variabel terikat, seperti yang ditunjukkan pada tabel 2 .

Tabel 2. Hasil Uji F

\begin{tabular}{llrrrrr}
\hline & Sum Of & df & Mean Square & F & Sig \\
\hline Model & Squares & & & & & \\
\hline 1 & Regression & 2182.412 & 3 & 727.471 & 134.517 & .000 \\
& Residual & 524.578 & 97 & 5.408 & & \\
\multicolumn{1}{l}{ Total } & 2706.990 & 100 & & & \\
\hline
\end{tabular}

a.Dependent Variable : Komitmen Guru

b. Predictors : (Constan), Motivasi Berprestasi, Kepemimpinan Kepala Sekolah, Iklim Sekolah

Untuk menguji hipotesis secara simultan (bersama-sama) digunakan statistik $\mathrm{F}$, dari hasil perhitungan dengan SPSS di atas diperoleh Fhitung $=134,517$ dan Ftabel dengan dk pembilang $=3$ dan $\mathrm{dk}$ penyebut $=98$ dengan $=0,05$ atau Ftabel $=\mathrm{F}(0,05)(3 ; 98)=2,71$. Dengan demikian, Fhitung $>$ Ftabel atau 134,517 > 2,71 maka H0 ditolak dan H1 diterima. Maka hasil "Terdapat pengaruh kepemimpinan kepala sekolah, iklim sekolah, dan motivasi berprestasi secara bersama-sama terhadap komitmen guru di SMK Sub Rayon 04 Kabupeten Ogan Komering Ulu Timur Provinsi Sumatera Selatan".

Pengaruh kepemimpinan kepala sekolah terhadap komitmen guru. Kepemimpinan kepala sekolah yang dikembangkan dengan baik akan membentuk iklim yang kondusif pada tempat kerja dapat menjadi faktor penunjang bagi peningkatan kinerja karena kenyamanan dalam bekerja membuat guru berpikir dengan tenang dan terkosentrasi hanya pada tugas yang sedang dilaksanakan. Kepemimpinan kepala sekolah dapat menemukan pendekatan untuk menyampaikan berbagai konsep yang diajarkan di dalam mata pelajaran tertentu sehingga semua siswa dapat menggunakan dan mengingat lebih lama konsep tersebut. Bagaimana setiap individual mata pelajaran dipahami sebagai bagian yang saling berhubungan dan membentuk satu pemahaman yang utuh bagaimana seorang guru dapat berkomunikasi secara efektif dengan siswanya yang selalu bertanya-tanya tentang alasan dari sesuatu, arti dari sesuatu, dan hubungan dari apa yang mereka pelajari. Bagaimana guru dapat membuka wawasan berpikir yang beragam dari seluruh siswa sehingga mereka dapat mempelajari berbagai konsep dan cara mengaitkannya dengan kehidupan nyata sehingga dapat membuka berbagai pintu kesempatan selama hidupnya. Kompetensi guru dapat dilihat dari kemampuan guru dalam melaksanakan tugas dan tanggung jawabnya yang tentunya sudah dapat mencermikan suatu pola kerja yang dapat meningkatkan mutu pendidikan kearah yang lebih baik. Seseorang akan bekerja secara profesional bilamana memiliki kemampuan kerja yang tinggi dan kesungguhan hati untuk mengerjakan dengan sebaik-baiknya. 
Sebaliknya, seseorang tidak akan bekerja secara profesional bilamana hanya memenuhi dua persyaratan di atas.

Kemudian, Pengaruh iklim sekolah terhadap komitmen guru. Komitmen merupakan salah satu perilaku seseorang yang memegang peranan penting bagi maju mundurnya sebuah organisasi yang mewadahinya dalam menjalankan profesinya adalah komitmen dari seorang guru. Komitmen seorang guru ini sangat ditentukan dari loyalitas, tetap berpegang teguh pada janji, dan keterikatan diri yang kuat terhadap upaya-upaya yang dilakukan dalam rangka meningkatkan mutu suatu organisasi adalah sekolah. Kaitannya adalah guru merupakan faktor penentu mutu pendidikan dan keberhasilan pendidikan di sekolah maka komitmen guru sangat diperlukan guna mengembangkan kualitas dan aktivitas tenaga kependidikan. Hal ini sejalan dengan pendapat Menurut Usman (2009:482), konsisten adalah sikap kokoh dan teguh pada pendirian meskipun berbagai ancaman, orang yang konsisten dapat diramalkan tingkah lakunya, tidak mudah berubah-ubah prilakunya (sikap dan perbuatan), ucapannya dan janjinya dapat dipercaya, serta sesuai antara perkataan dan perbuatan. Pengaruh iklim sekolah terhadap komitmen guru di SMK Sub Rayon 04 Kabupaten Ogan Komering Ulu Timur Provinsi Sumatera Selatan ini sesuai dengan hasil penelitian Fujianti (2012) yang berjudul: pengaruh komitmen guru terhadap iklim sekolah dan kepuasan kerja terhadap kinerja pendidik. Hasil penelitiannya menunjukkan terdapat pengaruh yang positif dan signifikan antara iklim sekolah terhadap komitmen guru. Maknanya adalah komitmen guru sudah melaksanakan tugasnya sebagai suatu profesi secara komitmen guru yang dituntut memiliki keahlian, tanggung jawab, dan kesetiannya terhadap komitmen yang diperoleh melalui pendidikan dan pelatihan.

Selanjutnya, Pengaruh motivasi berprestasi terhadap komitmen guru. Motivasi berprestasi merupakan pendorong bagi guru untuk tetap bekerja dengan optimal agar mencapai hasil terbaik. Guru yang bekerja tanpa ada motivasi berprestasi cenderung mudah mencapai titik jenuh dalam bekerja karena kejenuhan ini akan mengakibatkan merosotnya produktivitas. Dalam hal ini, tentu berdampak negatif bagi organisasi sekolah. Motivasi berprestasi merupakan elemen penting yang mesti dimiliki oleh setiap guru, adanya motivasi membuat guru bekerja dengan semangat, dan tidak mudah goyah. Motivasi dapat berupa dorongan dari dalam maupun dari luar diri guru. Adanya motivasi membuat guru bekerja dengan fokus dan konsisten untuk mencapai suatu tujuan. Pengaruh motivasi berprestasi terhadap komitmen guru di SMK Sub Rayon 04 Kabupaten Ogan Komering Ulu Timur provinsi Sumatera Selatan ini sesuai dengan hasil penelitian Triwidiastuti (2015), yang berjudul: komitmen guru, motivasi, dan pemenuhan jam mengajar guru di SMP di Kabupaten Karang anyar. Hasil penelitiannya menunjukkan terdapat pengaruh yang positif dan signifikan antara motivasi berprestasi terhadap komitmen guru. Bila motivasi dengan indikator sikap, kepercayan orang yang berada di lingkungan sekolah maupun di luar lingkungan sekolah, dan norma budaya sekolah dan hubungan antar individu yang ada di sekolah maka komitmen guru mengalami peningkatan. Hal ini berarti variabel motivasi memiliki pengaruh terhadap komitmen guru. Dari hasil ini menunjukkan bahwa komitmen guru merupakan salah satu perilaku seseorang yang memegang peranan penting bagi maju mundurnya sebuah organisasi yang mewadahinya dalam menjalankan profesinya. Dalam hal ini, komitmen dari seorang guru yang sangat ditentukan dari loyalitas, tetap berpegang teguh pada janji, dan keterikatan diri yang kuat terhadap upaya-upaya yang dilakukan dalam rangka meningkatkan mutu suatu organisasi dalam hal ini adalah sekolah.

\section{Kesimpulan}

Berdasarkan hasil penelitian dan analisis data yang telah dilakukan baik secara deskriptif maupun pengujian hipotesis dapat disimpulkan bahwa Terdapat pengaruh kepemimpinan kepala sekolah terhadap komitmen guru di SMK Sub Rayon 04 Kabupaten OKU Timur Provinsi Sumatera Selatan. Artinya semakin maksimal kepemimpinan yang diterapkan oleh kepala sekolah, maka komitmen guru akan semakin maksimal pula. 
Terdapat pengaruh iklim sekolah terhadap komitmen guru di SMK Sub Rayon 04 Kabupaten OKU Timur Provinsi Sumatera Selatan semakin baik kepemimpinan kepala sekolah di SMK Sub Rayon 04 Kabupaten OKU Timur Provinsi Sumatera Selatan, maka komitmen guru akan meningkat. Besarnya pengaruh kepemimpinan sangat ditentukan oleh peran kepala sekolah sebagai Educator, Manager, Administrator, Supervisor, Leader, Innovator dan motivator.

Terdapat pengaruh motivasi berprestasi terhadap komitmen guru di SMK Sub Rayon 04 Kabupaten OKU Timur Provinsi Sumatera Selatan. Artinya semakin baik motivasi di SMK Sub Rayon 04 Kabupaten OKU Timur Provinsi Sumatera Selatan, maka komitmen guru akan semakin meningkat. Besarnya pengaruh motivasi kerja ditentukan oleh kebutuhan fisiologis, kebutuhan rasa aman, kebutuhan sosial, kebutuhan penghargaan dan kebutuhan aktualisasi diri.

Terdapat pengaruh kepemimpinan kepala sekolah, iklim sekolah, dan motivasi berprestasi secara bersama-sama terhadap komitmen guru di SMK Sub Rayon 04 Kabupaten OKU Timur Provinsi Sumatera Selatan. Berarti jika hal ini antara kepemimpinan kepala sekolah, iklim sekolah dan motivasi kerja secara bersama-sama, maka komitmen guru di SMK Sub Rayon 04 Kabupaten OKU Timur Provinsi Sumatera Selatan akan meningkat, Kepemimpinan yang baik iklim sekolah yang kondusif dan Motivasi kerja yang tinggi maka akan meningkatkan komitmen guru yang lebih baik.Isi dari simpulan hendaknya berupa jawaban atas pertanyaan dan tujuan penelitian. Simpulan dipaparkan dalam satu paragraf, bukan poin-poin, dan diungkapkan bukan dalam kalimat statistik.

\section{Daftar Pustaka}

Ahmad, S. (2013). Ketahan Malangan Kepemimpinan Kepala Sekolah. Yogyakarta: Pustaka Felicha.

Astina, I. N. G., \& Sriathi, A. A. A. (2016). Pengaruh Gaya Kepemimpinan Dan Iklim Organisasi Terhadap Kepuasan Kerja Karyawan Di Pt. Billabong Indonesia. E-Jurnal Manajemen, 5(5).

Bashawa dan Grant. (2005). The impact of identification and commitment on job satisfaction The case of a Turkish service provider. International Journal of Behavior. www.emeraldinsight.com/0140-9174.htm. Diakses tanggal 2 September 2020.

Baihaqi, M. I. (2015). Indikator Keberhasilan Kepemimpinan Kepala Sekolah dan Motivasi Kerja Terhadap Kinerja Guru. Jurnal Konstruktivisme, 7(2).

Cahyani, A., Listiana, I. D., \& Larasati, S. P. D. (2020). Motivasi Belajar Siswa SMA pada Pembelajaran Daring di Masa Pandemi Covid-19. IQ (Ilmu Al-qur'an): Jurnal Pendidikan Islam, 3(01), 123-140.

Carson. (2007). validating teacher commitment. Jurnal of Univ. Malaysia, 11(2): 31-38.

Depdiknas. (2006). Standar Kompetensi Kepala Sekolah TK, SD, SMP, SMA, SMK, dan SLB. Jakarta: Cipta Karya.

Fernandez, S., Cho, Y. J., \& Perry, J. L. (2010). Exploring the link between integrated leadership and public sector performance. The Leadership Quarterly, 21(2), 308-323.

Kristiawan, M. (2014). Pengembangan Perangkat Lunak Model Peningkatan Kompetensi Guru dalam Pemanfaatan Komputer sebagai alat Bantu Pembelajaran. Disertasi Program Doktor Pascasarjana Universitas Negeri Padang .

Kesumawati, N. (2017). Pengantar Statistik Penelitian. Depok: Raja Grafindo Persasa.

Marrison. (2010). Corporate Culture and Performance. Academy of Management Journal, June, pp.452-463.

Mansur. (2018). Tantangan Kepemimpinan Kepala sekolah .

Nasution, M. N. (2010). Manajemen Mutu Terpadu (total quality managemen). Bogor: Ghalia Indonesia.

Novitasari, N., Djasmi, S., \& Rini, R. (2017). Pengaruh Kepemimpinan Kepala Sekolah, Iklim Motivasi Berprestasi Terhadap Komitmen Guru. Jurnal Manajemen Mutu Pendidikan, 5(1). 
Organ. (2007). The effect of organizational culture and leadership style on job satisfaction and organizational commitment across-National Comparison. The journal of manajement development, Vol 23, No. 4, 321-337.

Riduwan. (2010). Metode dan Teknik Menyusun Tesis. Bandung: Alfabeta.

Salami, S.O. (2008). Demographic and Psychological Factors Predicting Organizational Commitment among Industrial Workers. Anthropologist, 10 (1): 31-38

Septiana, R. (2013). Pengaruh Kepemimpinan Kepala Sekolah dan Motivasi Kerja terhadap Kinerja Guru SMP Negeri Wonosari. Jurnal Pendidikan UNS , 2 (1).

Sugiyono. (2014). Metodelogi Penelitian Kuantitif, Kualitatif, dan R and D. Bandung: Alfabeta.

Tampubolon, H. (2016). Hubungan Antara Motivasi Berprestasi Dan Budaya Organisasi Dengan Kepuasan Kerja Guru Smak Penabur Wilayah Jakarta Barat. Jurnal Manajemen Pendidikan, 5(2), 259-282.

Uno, H. B. (2007). Teori Motivasi \& Pengukurannya; analisis di bidang penidikan. Jakarta: Bumi Aksara.

Usman, H. (2009). Manajemen: Teori, Praktik, dan Riset Pendidikan. Jakarta: Bumi Aksara.

Wahid, E. (2011). Pengaruh Kepemimpinan Kepala sekolah, Budaya Organisasi dan Komitmen Organisasi terhadap Kinerja GUru pada SMP Negeri 3 Rancaekek. Jurnal Ekonomi Bisnis \& Entrepreneurship, 5 (2). 